\title{
The Newest African-Americans?: Somali Struggles for Belonging
}

\begin{abstract}
Cawo M. Abdi
America is God's crucible, the great Melting-Pot where all the races of Europe are melting and reforming!... The real American has not yet arrived. He is only in the crucible, I tell you - he will be the fusion of all races. - Israel Zangwill
\end{abstract}

Not merely a nation but a nation of nations. - Lyndon B. Johnson

\section{Introduction}

Migration anchors the essence of what it means to be an American. The "imagined community" is made up of individuals, their parents, grandparents or even great-grandparents, who crossed oceans to seek better pastures for their families. In other words, America is synonymous with migration. At its core, it remains characterized by the different waves of immigrants from across the world who, over the last five centuries, sought their fortunes and fates in this beautiful land. However, being an American is also a contested notion, one that over its long history too often failed to measure up to its ideals. The slavery of Africans as well as the brutal treatment and extermination of many Native Americans also anchor the idea of belonging to this nation. From the founding of the nation at the end of the 18th century, cracks and contradictions in its ideals continue to manifest themselves through institutionalized discrimination and the exclusion of certain groups within its diverse population.

It is this history of racial and class division and how it shapes the settlement experience of the latest waves of migrants today that will be the focus of this essay. Drawing from years of primary research with Somalis in Minnesota and Ohio and other regions of the globe as well as secondary data, I want to locate Somali migration experiences within the wider debates about integration and the path to citizenship. My aim is to provide a portrait of some of the key challenges Somalis are experiencing in urban America and their implications for settlement and "belonging." I argue that this community 
is reaping some of the benefits associated with migration while also becoming entrenched in inner-city, segregated urban America and is thus not enjoying full citizenship. The first part of the analysis provides a review of the assimilation debate and its iterations over the last century. I find that understanding this concept and the critiques leveled against it are essential for new migration streams into the United States. The second part of the article historicizes Somali migration and the context and content of the 1990s Somali influx into North America. This will be followed by a discussion of two key factors that I identify as being the bedrock of Somali experiences: Somali refugees' limited human capital and their ongoing financial obligations to families left behind. These factors are vital to Somalis' physical and emotional survival everywhere, while they also impede their settlement in America. The conclusion assesses the theoretical and policy implications of these challenges for citizenship and future Somali-American prospects.

\section{Migration Waves: Assimilation, Alienation, and In-Between}

The earliest scholars of migration explored the questions of identity and belonging, and the process of settlement and integration into the American community. These scholars, however, exclusively focused on the late 19th-century and early 20th-century European newcomers in metropolitan American cities. The Holy Grail in migration studies as to how to understand the Americanization process centers on the notion of assimilation. One 1921 definition of this concept came from the Chicago School, where Robert Park and E. W. Burgess defined it as "a process of interpenetration and fusion in which persons and groups acquire the memories, sentiments, and attitudes of other persons and groups and, by sharing their experience and history, are incorporated with them in common cultural life." ${ }^{1}$ This concept attempts to capture the process by which migrants take on the economic and socio-cultural characteristics of the majority population that they joined. ${ }^{2}$ Early studies on these ethnic groups found that assimilation was definitely a process that took generations. As Alba and Nee put it, "[It] was only with the third, and in some cases, the fourth generations that the powerful undercurrent of assimilation came unmistakably to the surface." ${ }^{3}$

The dominant framework was that European migrants would, over a mere few generations, "melt" into the American mainstream or become acculturated into what some scholars called American "core culture." ${ }^{4}$ Milton Gordon's view was in fact normative in that it idealized the 
white Protestant and Anglo-Saxon middle-class economic and sociocultural model as representing the culmination of assimilation in its full cycle. ${ }^{5}$ The political context in which this debate occurred explains the attractiveness of assimilation, or what Israel Zangwill called the ideal of the American "Melting Pot" of all races. This "offered an idealistic vision of American society and identity as arising from the biological and cultural fusion of different peoples." ${ }^{6}$ This nationalist vision attempted to erase or undermine ethnic attachments to distant lands and was in line with nationalist discourses in war times.

Different European groups, however, arrived at "assimilation" via different routes. For instance, unlike the earlier waves of Northern and Western European migrants, those from Eastern and Southern Europe experienced discrimination and even racialization that stigmatized them as inferior to the Anglo-Saxon stock in America. ${ }^{7}$ The newest European immigrants still strove to distinguish themselves from the African-Americans, who occupied the lowest rungs in the racial hierarchy in America. ${ }^{8}$ Their exclusion from the "core culture" was accompanied by their assertion of difference and superiority to African-Americans during the Jim Crow era. Despite their early experiences of racial and religious bigotry, these stigmatized groups eventually became part of the dominant "white" groups in America, as they integrated through socioeconomic mobility and intermarriage as well as residential integration. Other groups remained excluded from the assimilation debate. Illustrating their Eurocentricism in who was deemed capable of assimilation, early proponents of this position wrote:

In America it has become proverbial that a Pole, Lithuanian, or Norwegian cannot be distinguished, in the second generation, from an American born of native parents...As a matter of fact, the ease and rapidity with which aliens, under existing conditions in the United States, have been able to assimilate themselves to the customs and manners of American life have enabled this country to swallow and digest every sort of normal human difference, except the purely external ones, like color of the skin. ${ }^{9}$

Similarly, even scholars writing in late 20th century presented the inevitable "truth" of the racial dynamics in America already acknowledged by Park and Burgess. ${ }^{10}$ In this vein, Alba and Nee wrote in 1997 that: 
The most intractable racial boundary remains that separating those deemed phenotypically black from whites. This boundary is likely to exert a powerful influence on the adaptation possibilities of immigrant groups, depending on where they are situated with respect to it... . ${ }^{11}$

Understandably, then, the assimilation paradigm of the first part of the 20th century came under fire with the civil rights movement and the 1965 immigration law reforms, which transformed the source and the characteristics of immigrants. Prior to this time, American immigration laws curtailed non-European migration with discriminatory quotas that were only favorable to Europe. ${ }^{12}$ Hence, 1965 immigration policy reforms represented progressive attempts in line with the civil rights debates of the day and eliminated the legal discrimination embedded in earlier quota systems. These developments not only transformed policies dealing with American race relations, but also ushered in a new direction for assimilation debates.

Scholars focusing on post-1965 migration, which was dominated by non-Europeans, highlight how race and ethnicity factor in to the Americanization experience. The former disregard or even attempt to explain the experiences of African-Americans, as well as the diversity of the Asian and South American dominated migrations, undermined the old straight-line conceptualization of assimilation. The emerging discourse on migrant settlements analyzed the structural barriers intrinsic in American racial stratification and its consequences for migrants of color. Scholars such as Glazer, Moynihan, and Portes highlighted how racial stratification and structural conditions in America can block assimilation outright. This racial and ethnic disadvantage perspective brings to the fore how factors other than agency and social capital can play a pivotal role in whether groups integrate economically, residentially, and politically. This is not to say that race or ethnicity is solely a burden, but rather that these can be both resources as well as burdens in migrants' pursuit of mobility. ${ }^{13}$ A more recent extension of this debate combines the straight-line assimilation arguments with the ethnic/racial disadvantage paradigm. Portes' and Min Zhou's formulation of "segmented assimilation" underscores that while assimilation defined as upward mobility and integration of newcomers holds true for some skilled migrants enjoying high levels of human capital, the opposite is true for the majority of labor migrants of color, who also assimilate, but join those on the margins of American racial and socioeconomic stratification. ${ }^{14}$ Attention to the structural barriers 
that Americans on the margins - as well as millions of labor migrants with extremely limited human capital-confront in America is key to understanding the type of assimilation that occurs and how race and class factor into this process. This formulation pays attention to "the contextual, structural and cultural factors" that lead to divergent paths of assimilation. ${ }^{15}$

\section{Portrait: Somali Migration to America}

Somalis are part of an increasing African migration trend that commenced in the 1970s. Though migrants and refugees categorized as "Black" in the American racial scheme remain numerically small when compared to Asians and Latin Americans, this group nevertheless represents a significant segment of the American ethnic mosaic. According to the Population Reference Bureau, immigration accounted for "at least one-fifth of the growth in the U.S. black population between 2001 and 2006."16 Those from the African continent accounted for one-third of the foreign-born blacks in America in 2005. ${ }^{17}$ The African presence in the United States is intrinsically tied to the founding of this nation, when millions of enslaved Africans were transported for plantation work. Following the abolition of slavery in the early 19th century, there was virtually little or no migration from the African continent to the Americas. Black migration to the United States in the first part of the 20th century only consisted of small numbers originating in the Caribbean. This changed with the liberalization of immigration laws, which also coincided with technological advancements in travel as well as the independence of many African nations and subsequent economic and political turmoil in post-colonial Africa.

It is within this historical context that the political catastrophe in Somalia triggered one of the largest refugee resettlement programs in the United States. In fact, Somalis are the largest African refugee population in the U.S. today, accounting for 5.5 percent of all refugees admitted between 1983 and 2000, but 25.4 percent of those admitted between 2001 and 2005. ${ }^{18}$ For the latter time frame, only Cuba has sent more refugees to the U.S. (31.4\%). The state of Minnesota has become home to two of the largest refugee populations in recent history: the Hmong in the 1970s and 1980s, and the Somalis since the early 1990s. The Somali refugee presence in Minnesota owes much to the strong voluntary agencies (VOLAGs) in this Midwestern state. These organizations sponsor and assist refugee resettlement programs. A combina- 
tion of the very strong Minnesota economy in the early 1990s (with unemployment dipping to around 2 percent in the late 1990s, the lowest rate in the whole country ${ }^{19}$ ) and the presence of the robust refugee assistance network largely explain the Somali concentration in Minnesota. Chain migration naturally follows once you have a large enough number of any group establishing itself in a given metropolitan setting, with newcomers benefiting from the settlement experiences of earlier migrants, with their accumulated knowledge of local practices and institutions.

Somali migration to America is hence a recent phenomenon and only took off following the collapse of the Somali state in the late 1980s. Close to 100,000 Somalis have been granted refugee status since 1990. This number excludes those born in the United States, which is probably a significant population given this community's high birth rate. ${ }^{20} \mathrm{~A}$ small number of Somali students came to the U.S. in the 1960s through the 1980s. Some of these students returned once they completed their education, whereas some had no choice but to stay on in America, with a change in immigrant status from student to asylee or refugee. Thus, the analysis of Somali migration to America over the last two decades covers an extremely narrow span of time, and mostly involves data collected from the first generation and their children. The analysis and conclusions presented on Somali settlement thus represent reflections on the trajectory of this emerging community in its relations with other groups in America as well as its adjustment to its new home.

\section{Refugee Status, Family Obligations, and Relative Poverty}

Two key factors integral to understanding Somali settlement experiences in America are the limited human capital that they came with and their financial obligations to kin left behind. First, human capital refers to Somali refugees' overall educational levels and language and other knowledge and skills. While Somalis who came to the U.S. prior to the collapse had higher educational levels, the majority of newcomers had very low levels of formal schooling. The opportunities available to the majority of Somali youth to acquire formal education in a predominantly nomadic society were severely limited. Except for a small number who were educated through an English curriculum in the Northern parts of Somalia and another group that were educated either in Italian or Arabic in the South, formal educational institutions were non-existent in colonial Somalia. Positive legacies of the dictato- 
rial regime of Siad Barre were the Somali script in the early 1970s and the expansion of educational opportunities to a larger segment of the population in towns and cities. Educational opportunities involved primary and secondary education in Somali, with limited post-secondary educational prospects. Consequently, even Somali refugees who had some post-secondary education in the home country came to the Western world with very limited English language skills and with educational credentials that were difficult to transfer to American labor markets. This limited human capital has great ramifications for their settlement in America.

The second factor that is instrumental in our understanding of the Somali settlement experience involves the collapse of the Somali state in the late 1980s and the resulting displacement and impoverishment of millions whose physical and material security was utterly compromised. More than a million Somalis fled to Kenya and Ethiopia and in fact hundreds of thousands of them remain in a protracted refugee condition. Those who made it out of these difficult circumstances and who arrived in the developed world have left their immediate and extended family members in these precarious situations. Strong family ties inherited from Somali culture and the Islamic faith promote a commitment to support and provide for dozens or even hundreds of kin left behind. Such obligation is significant for Somali migration and settlement strategies and has real consequences for their socioeconomic tactics and attitudes toward their new society.

\section{Federal and State Refugee Assistance Laws}

Understanding the refuge experiences of survival in a context of dispersion and settlement in different parts of the globe is crucial in order to appreciate refugee agency while remaining cognizant of entrenched structural barriers migrants and refugees confront in America. The social and economic challenges Somali refugees are experiencing in the United States remain steep. In contrast to labor migrants, refugees automatically qualify for numerous types of federal, state, and local support to assist them in their settlement and integration process. Though refugee assistance in the form of cash that VOLAGs provide is limited to less than year, the majority of refugee families qualify for cash assistance, food stamps, and subsidized housing, as well as medical care, through their federal and state human and health services 
departments. This provision remains vital for poor refugees' economic and survival strategizing.

My ethnographic work within this community leads me to conclude that social services remain a crucial part of the economic survival of Somali refugees in America as well as other developed nations. A large segment of this refugee community, including intact families who have at least one parent working, depends on these services. State assistance is crucial for these families since one parent's salary is unlikely to meet the subsistence needs, the market price housing rental, and the skyrocketing private healthcare insurance required for a family. This holds true for most Somali men and women who either work in low-paying jobs in which healthcare is not provided, or work as taxi or truck drivers, or run small family stores that only cater to their co-ethnics.

There is rich scholarship that details the marginal economic opportunities available to low-skilled refugees in American metropolitan areas in the current post-Industrial economy. ${ }^{21}$ Access to state and federal support, which are reduced over a longer stay in the country, continues to be essential for refugee families whose decisions and economic strategizing require them to maximize public benefits as well as employment income. Like many other poor Americans, Somalis often combine work and public assistance, and thus benefit from many state and federal services as well as local charity organizations while pursuing educational and employment opportunities. Minnesota Family Investment Program (MFIP) data from the Minnesota Department of Human Services shows that an important segment of the Somali population relies on public assistance for their everyday survival. MFIP helps low-income families with children to meet their basic economic needs, through cash grants for a limited term of sixty months as well as with food stamps. This program also assists individuals in accessing skills and language training. Utilizing these services does not mean that these individuals are not in the labor force. On the contrary, Somalis on MFIP have higher average reported earned income than whites and African-Americans on this program, with an average monthly earning of $\$ 1,065$, second only to Asian-American income..$^{22}$ Urgent demands to support families left behind in conflict zones, whose needs take precedence over attempts to pursue educational and skills development, can hinder these commendable efforts. Stretching an income that is already low relative to the mainstream standard in order to meet the basic needs of multiple families unfortunately has major consequences for the refugee household in America. ${ }^{23}$ This cycle of work, public 
assistance, and financial remittances to families elsewhere diminishes the ability of individuals and families to save and to execute long-term financial planning for them and their children. Many resort to survival techniques that involve planning from month to month, placing them in a precarious socioeconomic position. Consequently, Somalis accounted for over six percent of all MFIP eligible adults in Minnesota from 2003 to 2009. This group is thus overrepresented on public assistance rolls and has lower levels of success in welfare-to-work efforts than all other groups, including Hmong refugees and African-Americans. ${ }^{24}$

The overall level of human capital in this refugee population in part explains the high dependency on government support. For example, Somalis have one of the lowest rates of high school completion of MFIP participants. ${ }^{25}$ Overrepresentation in government assistance ranks and its consequences also emerge from the recent American Community Survey, which highlights Somali refugees' marginal socioeconomic position within the larger American society. This report found that Somalis experience extreme poverty rates when compared to all groups, including other African migrants, other black migrants from the Caribbean, and African-Americans. The 2007 American Community Survey found Somalis to have the highest poverty rate of all newcomers to America, closely followed by those born in Iraq and the Dominican Republic. At a 51 percent poverty rate, this level of poverty was in fact four times the national rate in the U.S. for that year, and double that of African-Americans. ${ }^{26}$ This high poverty rate is in stark contrast with the average median income of Muslims in America, a group hailed as "Middle Class and mostly mainstream" by a recent Pew Research Center Report. Muslim Americans on average compare well to the U.S. public in terms of education and income, with 41 percent of Muslim families having an average median income of $\$ 50,000$ or more annually (compared to $44 \%$ of the general population). ${ }^{27}$ Consequently, Somalis arguably stand in an extreme position when compared to other Muslims in America, as well as to the African-American population, which on average fares worst in all social-economic indicators. Going back to our earlier theoretical discussions of how new groups might be integrated into their new societies, high poverty rates translate to Somali integration into the lowest strata in the racial and economic stratification in America.

This statistical data relating to welfare dependency, as well as the findings from the American Community Survey, are consistent with 
my findings from ethnographic work with the Somali community. What emerges from this research is the difficulty of securing sources of income that are sufficient to permit them to get off public assistance. This is especially the case for women with children, who in the Minnesota case account for 84 percent of Somali families on MFIP. ${ }^{28}$ Most of these individuals have very limited language and training skills, and thus have an extremely difficult time joining the labor force for any length of time. While pressured by MFIP to train and seek employment, hundreds of Somali women that I have interviewed report that they fail to let go of this safety net. Their only employment options are often in sectors like janitorial services that require them to work at night when they have childcare commitments. A small number of these women end up seeking strategies to extend their sixty-month eligibility on the grounds of health and disability. Again, while the trauma of civil war and the violence that followed probably explains some of these requests, such applications are often made out of desperation for the need for public assistance, which is critical to both their survival and the survival of their kin back in Africa.

In addition to income insecurity, access to decent housing remains an integral part of immigrants' integration. Consistent with the persisting racial and economic segregation in America, ${ }^{29}$ refugee newcomers become part of the American socioeconomic stratification that separates inner-city dwellers from those in suburbia. Inner-city America continues to be dominated by racially marginalized groups that are mostly composed of African-Americans and Hispanics. ${ }^{30}$ Moreover, inner-city areas are often plagued by crime, violence, and poorly performing schools. Refugees and many labor migrants of color who cannot afford high rental prices come into direct contact and competition with those in the lowest socioeconomic strata in the American community. These groups' inclusion into inner-city America supports the segmented assimilation approach that Portes and Zhou postulated, and results in the racialization of newcomers of color into the Black American category.

Somalis distinguish themselves from African-American inner-city residents. Their low level of human capital and their financial obligations to kin left behind, however, promote their active pursuit of affordable public housing. This produces the strong intra-ethnic resource of a highly developed Somali network to share information about public housing across the nation. Some families even travel to faraway places that do not have large refugee populations, such as North Dakota or 
Nashville, to secure public housing or Section 8 certificates, with the plan to eventually return to their original state. Clearly this testifies to the desperation for affordable housing that many refugees experience. Market costs of $\$ 1,000-\$ 1,500$ for apartments and houses remain out of reach for many who are reliant on government subsidies often combined with low-paid, unskilled work. That this income is shared with dozens of immediate and extended family members elsewhere and is thus stretched beyond its limits further makes public housing demand within this community understandable. The stigma mainstream Americans attach to inner-city housing was non-existent for Somali refugees when they got here. This is changing, however. Recent media coverage of Somalis living in very dangerous public housing complexes in Omaha, Nebraska, illustrates the discrepancy between the security concerns of these refugees, who fled from civil war, and the crime and drug problems that plague some of these inner-city areas. Somali families in this public housing became so terrorized by the constant threats and crime in their neighborhood that they stopped coming out of their houses, and even stopped sending their children to school. ${ }^{31}$

In states with significant numbers of Somalis, one can find whole public or subsidized housing complexes that are now predominantly Somali residential areas. Examples of these include the Cedar-Riverside area in Minneapolis, the Lexington complexes or Afton View apartments in St. Paul, and the Capital Park apartments in Columbus, Ohio. Some of these housing complexes were formerly African-American areas, but these have been replaced by a flow of Somalis who share information about the units and their availability, and thus create a "chain" replacement and concentration, or segregated, area. One positive consequence is the creation of a community niche within these alien urban centers where Somalis find psychological security within their own group. Moreover, these areas provide business opportunities for a small number of these refugees, with halal groceries and clothing stores, such as those in Karmel and Mall 24 in Minneapolis. But the overall depression that plagues these areas with low-performing schools and high crime rates persists and negatively impacts newcomers. Somalis are now becoming more apprehensive about the consequences of this type of housing for them and their children, but most continue to view affordable housing, no matter where this might be located and no matter its stigma, as a requirement in order to survive while fulfilling their multiple commitments to family members in different parts of the world. 
Public assistance and public housing are indisputably necessary for the initial survival of newcomers. Yet potential ramifications for the prospect of success of the "1.5 generation," or those who arrive as children to the U.S., as well as the second generation and beyond, require attention. Research on black Caribbeans in the U.S. shows that most first-generation Caribbean parents brought with them strong cultural and human capital. This group resisted American racialization schemes with concerted efforts to distinguish themselves from the African-American population-through overt usages of accent, through claims of having a better work ethic, and through assertiveness that differs from that of African-American employees. Many of their children nevertheless became integrated into the African-American inner-city cultural attitudes toward mainstream society as well as institutions. This represents "segmented assimilation," or the integration of different groups into various sectors of society, with the expectation that those immigrants whose socioeconomic and human capital most resembles those of African-Americans will fare worse than others. ${ }^{32}$ Mary Waters, who has done extensive work on this topic as it relates to West Indian migrants, cogently argues that these parents' strong cultural and human capital cannot compete with the institutionalized American racial discrimination. ${ }^{33}$ She shows how "residential segregation and de facto educational segregation" influence the life chances and future prospects of many in the second generation. ${ }^{34}$ The second-generation Caribbeans identify with their African-American peers with a perspective informed by a sense of exclusion, "outsiderness," and of not benefiting from the American dream. The experiences of "Black" immigrants are important for our Somali case study and especially for the prospects of the younger population in this group. Data from the Census Bureau shows that Somalis constituted the group with the youngest population of all foreign-born groups, with a median age of 26.8 (compared to an average median age of 36.7 for all U.S. residents). ${ }^{35}$ How the 1.5 generation as well as the very young first generation fare in the educational and employment spheres will influence the trajectory of Somalis either as part of the lowest strata in American society or as part of an integrated Muslim-American community, maintaining its cultural and religious identity while integrating into mainstream America.

Finally, integration in America entails enjoying the rights granted to all citizens, which intrinsically brings to the fore the role of the nationstate in allocating rights and responsibilities to its members. These 
rights include civil rights (rule of law, free speech, etc.), political rights (participating in the political process, elections, voting, etc.), and social rights (provision of welfare, health care, unemployment insurance, disability insurance, etc.). The degree of provision of any given right, however, differs from country to country in most developed Western democracies. For example, the social rights provided to Canadians or to the British, such as universal health care, continue to be contested in the United States. Also, accessing federal public services is highly stigmatized in the American context, in which social citizenship debates lag those of Europe. ${ }^{36}$ Fraser and Gordon point out that in the United States:

Receipt of welfare is usually grounds for disrespect - a threat to, rather than a realization of, citizenship. In the area of social services, the word 'public' is often pejorative. Public hospitals are institutions of last resort, sites of stigma, not solidarity. The connotations of citizenship are often positive, powerful, and proud, while those of welfare are so negative, weak, and degraded that social citizenship here sounds like an oxymoron. ${ }^{37}$

Fraser and Gordon's discussion of this stigma highlights a key challenge Somalis confront to full citizenship in the American context. Of course, other poor and marginalized groups also experience this challenge, which involves how individuals in any given society actively engage in shaping their nation-state. As Isin and Siemiatycki put it, "citizenship is not a static experience: citizens actively struggle to change both the meaning and boundaries of citizenship itself." 38 Thus, citizenship becomes a practice, a lived experience, in which members of a given society shape and are also shaped by full engagement with the social, economic, and political institutions that prevail in a given historical moment. ${ }^{39}$ Somali migration at its core was due to a failure of the freedom to practice citizenship, with dictatorial rule that limited all rights and then with myopic warlords that toppled one dictator to subject people to multiple forms of terror. One can argue that the notion of citizenship in both its legal and sociological varieties is a new concept for Somalis living in the American context. Access to public services, protection from violence, and the ability to vote (once naturalized) are all common rights that Somalis are accessing. But Somali experiences of pervasive poverty and segregation, as well as their classification 
as a pariah public burden-or what Fraser and Gordon call "charity cases" - can curtail their full exercise of citizenship. ${ }^{40}$

\section{Conclusion}

This essay has two conceptual and two policy implications that I would like to emphasize. It is important to reiterate the very short time span that has passed since Somalis settled in the United States in large numbers. Their struggles are in many ways consistent with what earlier groups with similar socioeconomic and educational backgrounds endured. Hence, one should not read this analysis as a suggestion that their current condition is their destiny. Theoretically, the Somali case reinforces the trends observed in earlier analyses, such as Portes' and Zhou's, which point out the barriers to integration that unskilled, post-1965 migrants of color confront in the American arena. ${ }^{41}$ This case study shows how Somalis' low level of human capital contributes to their marginalization in the United States. However, there is a dual process at play in this case: while segmented assimilation stresses the process of new groups with low human capital joining those on the margins of society, this Somali case study shows how they voluntarily segregate and distinguish themselves from African-Americans. This group is also involuntarily being segregated from mainstream white America by socioeconomic imperatives pushing them into public housing. Thus, the nature of the Somali location in the American stratification system testifies to this refugee groups' agency in rejecting American racialization schemes, while structural conditions place them in marginal inner-city ghettoes. Given the recent nature of Somali migration, it is difficult to know how the 1.5 generation and the second generation will fare, but trends observed in the schooling and resources available in the areas in which Somalis are concentrating indicate a continuation of this segregation and further marginalization within the wider American society.

A second conceptual implication relates to the exercise of citizenship. While segregation might provide a certain level of security for a group thanks to ethnic cooperation and shared resources, its longterm impact is detrimental for all of society. It undermines shared interests across racial and class divisions. Moreover, limited contact across groups entrenches prejudices and separation, with some groups becoming further excluded from belonging to the imagined community. ${ }^{42}$ The irony is that while Somalis' co-ethnic interdependency in 
America, as well as with their kin elsewhere, represents the ultimate citizenship ideal of common destiny and mutual obligation and solidarity, their exclusion and limited resources in America place them on the margins of mainstream America's understanding of social rights. That view is intrinsically based on the "contractual" agreement whereby only those who contribute to the pot may draw benefits from the social contract. ${ }^{43}$ Somalis contribute to different pots: one in Somalia, where millions of people are surviving thanks to remittances from low-wage and low-prestige employment in America, often combined with American social service benefits. They also contribute to an American pot in the form of cheap labor. These contributions, however, are viewed as incommensurate with what they draw out, which can generate resentment from mainstream Americans who stigmatize them as burdensome and parasitic.

This essay also provides two important policy ideas. A community that is relatively new and relies heavily on public provisions is bound to face a backlash on the policy front. Similar to some European nations, the current economic recession the United States is pushing for severe austerity measures that include restrictions on public assistance. Despite this environment, understanding the multiple competing obligations that migrants and refugees negotiate everyday can help policymakers better address the challenges migrants confront in their integration process. For migrants to reap the myriad opportunities America provides, there needs to be a more concerted effort to incorporate them into the American fold, through better-funded programs to build migrant and refugees' meager human capital. Such investment enriches the American mosaic and the American economy, with newcomers fostering a rich, diverse, and productive American labor force.

Second, an investment in programs that promote a better understanding of what it means to be an American, with knowledge of the beauty as well as the ugly scars in the history of this great nation, can also accelerate the newcomers' process of integration. Such understanding would permit newcomers to appreciate the long struggles of minorities, such as African-Americans, as well as the contentious dynamics of nation building in which Americans of all races participated. Such an investment would support new immigrants in better understanding their citizenship rights as well as obligations. The absence of such policy-level efforts will lead to limited immigrant engagement with the greater society and with American institutions. This can only further entrench their marginalization and undermine their participation in 
the political process. Remaining on the margins of society entails devastating long-term repercussions for future Somali-Americans, and we all have an obligation to prevent such a calamity.

\section{Notes}

1. R. E. Park and E. W. Burgess, Introduction to the Science of Sociology (Chicago: University of Chicago Press, 1921).

2. Susan K. Brown and Frank D. Bean, "Assimilation Models, Old and New: Explaining a Long-Term Process," Migration Information Source (MPI) (2006), retrieved online at migrationinformation.com/USfocus/pring.cfm?ID=442.

3. Richard Alba and Victor Nee. "Rethinking Assimilation Theory for a New Era of Immigration," International Migration Review 31, no. 4 (1997): 826-874.

4. Milton Gordan, Assimilation in American Life (New York: Oxford University Press, 1964).

5. Ibid.

6. Alba and Nee 1997.

7. Peter Schuck, “The Transformation of Immigration Law," Columbia Law Review 84 (1984): 1-90.

8. Noel Ignatiev, How the Irish Became White (New York: Routledge, 1964).

9. Park and Burgess 1921.

10. Ibid.

11. Alba and Nee 1997.

12. Richard Delgado, "Citizenship," in Immigrants Out! The New Nativism and the AntiImmigrant Impulse in the United States, edited by Juan F. Perea, 318-323 (New York: New York University Press, 1997); and Center for Immigration Studies, “Three Decades of Mass Immigration: The Legacy of the 1965 Immigration Act" (1995), retrieved online at cis.org/articles/1995/back395.htmlies.1995.

13. Nathan Glazer and Daniel P. Moynihan, Beyond the Melting Pot: The Negroes, Puerto Ricans, Jews, Italians, and Irish of New York City (Cambridge, Mass.: M.I.T. Press, 1970).

14. Alejandro Portes and Zhou Min, "The New Second Generation: Segmented Assimilation and its Variants among Post-1965 Immigrant Youth," Annals of the American Academy of Political and Social Science 530 (1993): 74-98.

15. Brown and Bean 2006.

16. Mary Mederios Kent, "Immigration and America's Black Population," Population Reference Bureau (2007), retrieved online at 69.93.135.52/pdf07/62.immigration.pdf.

17. Ibid.

18. Ibid.

19. “Minnesota's Job Market: Land of 1,000 Opportunities," The Economist (1999), retrieved online at economist.com/node/208084.

20. Barbara J. Ronningen, "Estimates of Selected Immigrant Populations in Minnesota," Minnesota State Demographic Center, Population Notes (2004), retrieved online at demography.state.mn.us/PopNotes/EvaluatingEstimates.pdf; and Minnesota Department of Human Services, "Racial/Ethnic and Immigrant Groups Participating in the 


\section{Bildhaan Vol. 11}

Minnesota Family Investment Program and the Diversionary Work Program," REIS \#15 (2009).

21. William Julius Wilson, Jobless Ghettoes: The Disappearance of Work and its Effect on Urban Life (New York: Knopf, 1991); and Roger Waldinger and Jennifer Lee, “New Immigrants in Urban America" in Strangers at the Gates, edited by Roger Waldinger, 30-79 (Berkeley: University of California Press, 2001).

22. Minnesota Department of Human Services 2009.

23. Cawo Abdi, "Diasporic Lives and Threatened Identities: Gender Struggles of Somalis in America," Ph.D. Dissertation, Department of Sociology, University of Sussex, East Sussex, U.K. (2006).

24. Minnesota Department of Human Services, "Measuring Minnesota Family Investment Program Performance for Racial/Ethnic and Immigrant Groups," Study Brief \#7 (2003), retrieved online at dare-todream.us/cultural_competency/MN/ MN\%20MFIP\%20Disparities.pdf.

25. Minnesota Department of Human Services 2009.

26. U.S. Census Bureau, "Income, Poverty, and Health Insurance Coverage in the United States 2007" (2008), retrieved online at census.gov/prod/2008pubs/p60-235.pdf.

27. Pew Research Center Report, "Muslim Americans: Middle Class and Mostly Mainstream" (2007), retrieved online at pewresearch.org/pubs/483/muslim-americans.

28. Minnesota Department of Human Services 2009.

29. Wilson 1995; Douglas Massey, "The New Immigration and Ethnicity in the United States," Population and Development Review 21, no. 3 (1995): 631-649; William W. Goldsmith, "From Metropolis to Globalization: The Dialectics of Race and Urban Form" in Readings in Urban Theory, 2nd edition, edited by Susan S. Fainstein and Scott Campbell, 129-149 (Cambridge, Mass.: Blackwell Publishing, 2002); Paul A. Jargowsky, "Take the Money and Run: Economic Segregation in U.S. Metropolitan Areas," American Sociological Review 61, no. 6 (1996): 984-998; and Camille Zubrinsky Charles, "The Dynamics of Racial Residential Segregation," Annual Review of Sociology 31 (2003): 167-207.

30. Ibid.

31. Action 3 News, "Security Stepped Up at Southside Terrace" (2010), retrieved online on 28 January 2011 at wardheernews.com/News_2011/Jan/28_security_stepped_up_at_ south_side_terrace.html.

32. Portes and Zhou 1995; and H. H. Gans, "Second-Generation Decline: Scenarios for the Economic and Ethnic Futures of the Post-1965 American Immigrants," Ethnic and Racial Studies 15 (1992): 173-192.

33. Mary Waters, Black Identities: West Indian Immigration Dreams and American Realities (Cambridge, Mass.: Harvard University Press, 1999).

34. Ibid.

35. U.S. Census Bureau, "Census Bureau Data Show Characteristics of the U.S. ForeignBorn Population" (2009), retrieved online at census.gov/newsroom/releases/archives/ american_community_survey_acs/cb09-cn01.html.

36. Roger Lawson and William Julius Wilson, "Poverty, Social Rights, and the Quality of Citizenship," in Readings in Urban Theory, 2nd edition, edited by Susan S. Fainstein and Scott Campbell (Cambridge, Mass.: Blackwell Publishing, 2002), p. 160. 
Cawo M. Abdi

37. Nancy Fraser and Linda Gordon, "Contract versus Charity: Why Is There No Social Citizenship in the United States?," in The Citizenship Debate: A Reader, edited by Gershon Safir (Minneapolis: University of Minnesota Press, 1998), p. 114.

38. Engin F. Isin and Myer Siemiatycki, "Fate and Faith: Claiming Urban Citizenship in Immigrant Toronto," Working Paper No. 8, Working Paper Series, Joint Centre of Excellence for Research on Immigration and Settlement, Toronto, Canada, 1999.

39. Ibid.

40. Fraser and Gordon 1998.

41. Portes and Zhou 1993.

42. Goldsmith 2002.

43. Fraser and Gordon 1998, p. 124. 